\title{
STUDI KOMPARATIF: KUALITAS HIDUP KLIEN HIV(+) YANG MENGGUNAKAN DAN TIDAK MENGGUNAKAN ANTIRETROVIRAL THERAPY DI BANDUNG
}

\author{
Linlin Lindayani \\ STIKEP PPNI JAWA BARAT \\ Email: linlinlindayani@gmail.com
}

\begin{abstract}
ABSTRAK
HIV merupakan masalah kesehatan global dan penyebab kematian terbesar didunia. Sampai saat ini tidak ada obat yang bisa menyembuhkannya, yang baru muncul yaitu terapi dengan pemberian antiretroviral yang dapat menurunkan angka kematian dan meningkatkan umur harapan hidup. Klien HIV (+) yang menggunakan ART akan merasakan dampak dari penggunaan ART sedangkan pada klien HIV $(+)$ yang tidak menggunakan ART akan merasakan dampak dari penurunan kondisi kesehatannya akibat HIV yang akan menyertainya sepanjang hidup. Kondisi tersebut akan berpengaruh terhadap kualitas hidupnya. Penelitian ini bertujuan untuk membandingkan dimensi kualitas hidup klien HIV $(+)$ yang menggunakan dan tidak menggunakan ART. Penelitian ini bersifat deskriptif komparatif. Teknik sampling menggunakan Convenience Sampling. Sampel yang diteliti terdiri dari klien HIV $(+)$ yang mengggunakan ART sebanyak 42 orang dan klien HIV $(+)$ yang tidak menggunakan ART sebanyak 41 orang. Hasil penelitian dianalisis secara deskriptif dengan tabel ditribusi frekuensi, mean dan standar deviasiny, dilanjutkan dengan perhitungan statistik menggunakan Uji F, dan dilanjutkan dengan uji beda menggunakan Uji t. Hasil penelitian ini menunjukan bahwa dimensi kesehatan fisik, dimensi hubungan sosial dan dimensi lingkungan klien HIV (+) yang menggunakan ART lebih baik dibandingkan klien HIV (+) yang tidak menggunakan ART. Sedangkan untuk dimensi psikologisnya tidak terdapat perbedaan yang signifikan. Dengan mengetahui perbedaan kualitas hidup klien HIV $(+)$ yang menggunakan dan tidak menggunakan ART, diharapkan dapat menjadi bahan masukan bagi perawat dan lembaga swadaya masyarakat yang bergerak dalam pencegahan dan penangggulangan HIV dalam meningkatkan mutu pelayanannya sehingga mampu membantu mempertahankan dan meningkatkan kualitas hidup Klien HIV (+) baik yang menggunakan ataupun tidak menggunakan ART seoptimal mungkin.
\end{abstract}

Kata kunci: Antiretroviral Therapy, HIV, \& Kualitas Hidup

\section{ABSTRACT}

HIV is a global public health issues and caused large number of death. There is no cure that can treat or kill the disease, but only antiretroviral drugs are available to reduce mortality and improve their life expectancy. HIV-infected persons who receiving antiretroviral therapy (ART) will have impact on their quality of life as well as those who are not receiving such treatment yet. The purpose of this study was to compare domain of quality of life of people who receiving ART with those without ART. This is a comparative cross sectional study with convenience sampling. A total of 84 people living with HIV, including 42 who receiving ART and 42 were not under ART yet. Quality of life was measure using WHOQOL-HIV in brief version. Data were analyzed using independent $t$ test and $F$ test. The results of this study showed that people who receiving ART had significantly higher score of physical, social, and environmental domains of quality of life as compare to those without ART. However, we did not found statistically significant for psychological dimension between two groups. The results of this study can be considered for health care professional to improve quality of care for people living with HIV in Indonesia.

Keywords: Antiretroviral therapy, HIV \& Quality of life. 


\section{PENDAHULUAN}

HIV/AIDS merupakan masalah kesehatan global dan penyebab terbesar kematian di dunia. Perkembangan jumlah penderita HIV/AIDS mengalami peningkatan yang signifikan dari tahun ke tahun. Secara kumulatif pengidap infeksi HIV dan kasus AIDS di Indonesia dari 1 Januari 1987 s.d. 31 Desember 2016 adalah 198.219 orang HIV (+), 77.940 orang mengidap AIDS, sedangkan angka kematian yang disebabkan AIDS mengalami penurunan dari $13.86 \%$ pada tahun 2004 menjadi $0.02 \%$ pada tahun 2016 (Depkes RI, 2016). Provinsi Jawa Barat menempati urutan keenam untuk prevalnsi HIV/AIDS dengan jumlah 1543 HIV(+), 1578 orang AIDS, 283 orang meninggal karena HIV/AIDS (Depkes RI, 2016). Sejak tahun 2004, pemerintah Indonesia sudah menyediakan ART secara gratis (Depkes RI, 2016). Penelitian sebelumnya sudah mampu membuktikan bahwa ART mampu menurunkan angka kematian yang disebabkan karena AIDS (Chu \&Selwyn, 2011).

$$
\text { Antiretroviral Therapy (ART) }
$$

merupakan terapi dengan pemberian Obat antiretroviral (ARV). Akan tetapi, tidak semua klien HIV (+) menggunakan ART. Obat ARV memiliki kemampuan dalam mengurangi replikasi virus HIV (tidak membunuh) sehingga jumlah virus bisa ditekan dan sistem kekebalan tubuh tetap dapat dilindungi dari kerusakan. Hal tersebut ditandai dengan naiknya jumlah sel CD4 (tipe sel darah putih yang mengaktifkan sistem kekebalan tubuh untuk melawan penyakit) sehingga klien punya kesempatan untuk bisa bertahan hidup lebih lama serta bisa mengurangi angka kesakitan (Depkes RI, 2007).

Pada klien HIV (+) yang menggunakan ART, terdapat beberapa aspek dari statusnya sebagai HIV $(+)$ yang sedang menjalani terapi antiretroviral yang akan menyertai seumur hidupnya dan dapat berpengaruh terhadap kualitas hidup. Aspek-aspek tersebut yaitu: 1) Manfaat obat ARV: meningkatkan jumlah
CD4, viral load menurun; 2) Adanya tuntutan yang terus-menerus selama hidup klien terhadap perawatan, seperti pengaturan diet, pembatasan aktifitas, monitoring jumlah CD4; 3) Ketakutan akan atau akibat adanya komplikasi yang menyertai dan efek samping obat ARV; 4) penggunaan ARV dalam jangka waktu yang panjang (seumur hidup): tingkat ketergantungan terhadap obat ARV tinggi; 5) kepatuhan dalam pemakaiaan ART; 6) Adanya Stigma negatif dari masyarakat: isolasi sosial, pemutusan kerja (PHK); 7) Akses terhadap pelayanan kesehatan yang berkualitas.

Pada klien HIV (+) yang tidak menggunakan ART akan merasakan dampak dari statusnya sebagai klien HIV (+) saja, tidak merasakan dampak dari statusnya sebagai seorang yang sedang menjalani terapi antiretroviral. Hal tersebut akan menyertai seumur hidupnya sehingga akan berpengaruh terhadap kualitas hidup. Beberapa aspek dari HIV yang mempengaruhi kualitas hidup yaitu; 1) Akibat menurunnya sistem kekebalan tubuh: muncul infeksi oportunistik, berkurangnya kemampuan untuk beraktifitas sehingga penderita menjadi kurang produktif; 2) Adanya tuntutan yang terus-menerus selama hidup perawatan, seperti pengaturan diet, pembatasan aktifitas, monitoring jumlah CD4; 3) Adanya Stigma negatif dari masyarakat: isolasi sosial, pemutusan kerja (PHK); 4) Ketakutan akan perkembangan penyakitnya dan pemakaian ART dikemudian hari; 5) Akses terhadap pelayanan kesehatan yang berkualitas.

Keseluruhan aspek yang ada pada klien HIV (+) yang menggunakan dan tidak menggunakan ART tersebut akan berpengaruh terhadap dimensi kualitas hidupnya dan terhadap keseluruhan kualitas hidupnya. Kualitas hidup telah digambarkan oleh WHO (1994) sebagai sebuah persepsi individu terhadap posisi mereka dalam kehidupan pada konteks budaya dan sistem nilai dimana mereka tinggal/hidup, dan dalam hubungannya dengan tujuan hidup, harapan, 
standar dan fokus hidup mereka. Konsep ini meliputi beberapa dimensi yang luas yaitu: kesehatan fisik, kesehatan psikologis, hubungan sosial dan lingkungan. Keempat dimensi kualitas hidup tersebut akan berdampak secara holistic baik pada klien HIV (+) yang menggunakan maupun yang tidak menggunakan Antiretroviral Therapy.

Pengkajian kualitas hidup klien HIV (+) yang menggunakan dan tidak menggunakan Antiretroviral Therapy sangat penting karena tujuan upaya pelayanan kesehatan pada Klien HIV (+) bukan hanya mencegah tejadinya infeksi oportunistik, mengurangi angka kesakitan dan kematian tetapi juga upaya untuk meningkatkan kualitas hidupnya. Hal ini relevan dengan area keperawatan, karena keperawatan memandang klien secara holistik dari segi biologi, psikologis, sosialkultural, dan spiritual sehingga perawat dapat membantu klien HIV (+) dalam mempertahankan atau meningkatkan kualitas hidupnya, serta membuat perubahan-perubahan yang dibutuhkan dalam hidupnya khususnya hidup dengan HIV (+).

\section{METODE}

\section{Jenis penelitian}

Jenis penelitian yang digunakan dalam penilitian ini adalah deskriptif komparatif dengan pendekatan cross sectional, dimana penelitian ini berhubungan dengan situasi yang diselidiki dan membandingkan suatu kelompok atau objek berbeda dari yang lainnya dalam waktu bersamaan (Polit \& Hunger,2010).

\section{Populasi}

Dalam penelitian ini populasinya adalah semua klien HIV (+) yang menggunakan dan tidak menggunakan Antiretroviral Therapy di Bandung yaitu sebanyak 446 orang dengan kriteria: Termasuk klien HIV (+) yang sudah menjalani terapi Antiretroviral selama minimal enam bulan dan klien HIV (+) yang tidak menjalani terapi Antiretroviral (setelah minimal enam bulan didignosa sebagai HIV $(+)$ ). Adapun sampel yang diteliti yaitu 42 klien HIV $(+)$ yang menggunakan Antiretroviral Therapy dan 40 klien HIV (+) yang tidak menggunakan Antiretroviral Therapy. Pengambilan sampel ditentukan dengan teknik convenience Sampling.

\section{Teknik Pengumpulan Data}

Data dalam penelitian ini menggunakan angket tertutup yang sudah baku. Kualitas hidup klien HIV $(+)$ diukur mennggunakan instrumen kualitas hidup bentuk ringkas dari World Health Organization Quality of Life HIV BREF (WHOQOL-HIV BREF) berbentuk angket yang sudah diterjemahkan ke dalam bahasa Indonesia. Angket tersebut menggunakan skala likert yang terdiri dari 31 pertanyaan. Untuk item dimensi kualitas hidup, digolongkan kedalam 5 rentang skala likert, dimana nilai 5 menunjukan nilai yang tertinggi dan 1 nilai terendah. Skor item pertanyaan dengan arah positif, semakin tinggi skala (mendekati angka 5) menunjukkan kualitas hidup yang meningkat pula. Berbeda dengan skor item pertanyaan dengan arah negatif, semakin rendah skala (mendekati angka 1) menunjukkan kualitas hidup yang meningkat (Ibrahim, 2004).

\section{Analisa data}

Di analisa perdimensi dengan cara: 1) dicari nilai rata-rata/mean dan standar deviasi dari setiap item pertanyaan yang berhubungan dengan aspek-aspek dalam dimensi kualitas hidup. dicari nilai rata-rata/mean dan standar deviasi dari setiap total item pertanyaan yang berhubungan dengan setiap dimensi kualitas hidup kemudian setelah itu dikalikan dengan 4. 2) Skor rata-rata setiap aspek pada dimensi kualitas hidup berada pada $1-5$, nilai mean yang tinggi yang mendekati nilai 5 dari setiap aspek pada dimensi kualitas hidup menunjukkan bahwa klien puas dengan aspek pada dimensi kualitas hidup itu. Skor rata-rata setiap dimensi kualitas hidup berada pada rentang nilai $4-20$, nilai mean yang 
mendekati nilai 20 menunjukkan bahwa klien puas dengan dimensi itu. Semakin tinggi nilai mean dari setiap dimensi atau item, maka semakin tinggi pula tingkat kualitas hidup klien tersebut. Kemudian untuk mengetahui perbedaannya, pertama dilakukan uji homogenitas varian populasi dengan uji $\mathrm{F}$ dan beda perbandingan kualitas hidup metode uji $\mathrm{t}$ independent sample test.

\section{HASIL}

\section{Karakteristik Responden}

Dari tabel 1 dapat dilihat bahwa dari 42 responden HIV $(+)$ yang menggunakan ART dan 40 responden HIV (+) yang tidak menggunakan ART, menunjukan bahwa rentang usia mereka tidak jauh berbeda yaitu sebagian besar berada pada rentang usia 2029 tahun. Pada klien HIV (+) yang menggunakan ART jumlah responden lebih banyak laki-laki sedangkan pada klien HIV (+) yang tidak menggunakan ART jumlah responden lebih banyak perempuan. Status maritalnya tidak berbeda jauh, mereka ratarata belum menikah. Tingkat pendidikan ratarata sama serbagian besar SMA. Cara penularannya sebagian besar responden melalui drug injeksi.

Tabel 1. Distribusi frekuensi data demografi klien HIV (+) yang menggunakan dan tidak menggunakan ART

\begin{tabular}{|c|c|c|c|c|}
\hline \multirow[t]{2}{*}{ Karakteristik } & \multicolumn{2}{|c|}{$\begin{array}{l}\text { Klien HIV (+) yang } \\
\text { Menggunakan ART }\end{array}$} & \multicolumn{2}{|c|}{$\begin{array}{c}\text { Klien HIV (+) yang tidak } \\
\text { Menggunakan ART }\end{array}$} \\
\hline & Frekuensi & $\%$ & Frekuensi & $\%$ \\
\hline \multicolumn{5}{|l|}{ Umur (tahun) } \\
\hline $20-29$ & 31 & 73,8 & 33 & 82,5 \\
\hline $30-39$ & 11 & 26,2 & 7 & 17,5 \\
\hline \multicolumn{5}{|l|}{ Jenis Kelamin } \\
\hline Perempuan & 11 & 26,2 & 21 & 52,5 \\
\hline Laki-laki & 31 & 73,8 & 19 & 47,5 \\
\hline \multicolumn{5}{|l|}{ Status Marital } \\
\hline Belum menikah & 20 & 47,6 & 16 & 40,0 \\
\hline Menikah & 12 & 28,6 & 16 & 40,0 \\
\hline Janda/duda & 10 & 23,8 & 8 & 20,0 \\
\hline \multicolumn{5}{|l|}{ Pendidikan } \\
\hline Tidak sekolah & 1 & 2,4 & 1 & 2,5 \\
\hline SMP & 1 & 2,4 & 2 & 5,0 \\
\hline SMA & 26 & 61,9 & 25 & 62,5 \\
\hline $\mathrm{PT}$ & 14 & 33,3 & 12 & 30,6 \\
\hline \multicolumn{5}{|l|}{ Cara Tertular } \\
\hline Homoseksual & 2 & 4,8 & - & - \\
\hline Heteroseksual & 2 & 4,8 & 4 & 10,0 \\
\hline Drug injeksi & 36 & 85,7 & 26 & 65,0 \\
\hline Lain-lain (dari pasangan) & 2 & 4,8 & 10 & 5,0 \\
\hline Jumlah & 42 & 100 & 40 & 100 \\
\hline
\end{tabular}

\section{Informasi Kesehatan}

Tabel 2 menunjukan bahwa kondisi kesehatan pada klien HIV (+) yang menggunakan ART saat ini baik sedangkan pada klien HIV yang tidak menggunakan ratarata kondisi kesehatan sekarang biasa-biasa saja. Pada kedua responden, rata-rata hampir sama bahwa mereka saat ini tidak sedang menderita penyakit lain selain HIV (+). Akan tetapi status HIV mereka berbeda, klien HIV
$(+)$ yang menggunakan ART lebih banyaknya simtomatik sedangkan pada klien HIV $(+)$ yang tidak menggunakan ART lebih banyaknya asimtomatik.

\section{Dimensi Kualitas Hidup}

Dari tabel 3 dapat diinterpretasikan bahwa pada dimensi kesehatan fisik, klien HIV (+) 
yang menggunakan ART lebih puas terhadap kemampuannya dalam bergaul dan kurang puas akan istirahat dan tidurnya. Sedangkan klien HIV $(+)$ yang tidak menggunakan ART lebih puas terhadap kebutuhan pertolongan medis dan merasa kurang puas terhadap kemampuaannya untuk beraktifitas.

Tabel 2. Distribusi Frekuensi Informasi Kesehatan Klien HIV (+) yang Menggunakan dan Tidak Menggunakan Antiretroviral Therapy di Bandung, 2008

\begin{tabular}{|c|c|c|c|c|c|}
\hline \multirow[t]{2}{*}{ Karateristik } & \multicolumn{2}{|c|}{$\begin{array}{l}\text { Klien HIV (+) yang } \\
\text { Menggunakan ART }\end{array}$} & \multicolumn{2}{|c|}{$\begin{array}{c}\text { Klien HIV }(+) \text { yang Tidak } \\
\text { Menggunakan ART }\end{array}$} & \multirow{2}{*}{$\underset{\text { Responden }}{\sum \text { Total }}$} \\
\hline & Frekuensi & $\%$ & Frekuensi & $\%$ & \\
\hline \multicolumn{6}{|c|}{ Kondisi Kesehatan sekarang } \\
\hline Sangat kurang baik & 2 & 4,8 & 2 & 5,0 & \\
\hline Kurang baik & 6 & 14,3 & 9 & 22,5 & \\
\hline Biasa-biasa saja & 13 & 31,0 & 13 & 32,5 & \\
\hline Baik & 14 & 33,3 & 11 & 27,5 & \\
\hline Sangat baik & 7 & 16,7 & 5 & 12,5 & \\
\hline \multicolumn{6}{|c|}{ Penyakit lain sedang yang diderita } \\
\hline Ada & 11 & 26,2 & 10 & 25,0 & \\
\hline Tidak ada & 31 & 73,8 & 30 & 75,0 & \\
\hline \multicolumn{6}{|l|}{ Status HIV } \\
\hline Simtomatik & 34 & 81,0 & 18 & 45,0 & \\
\hline Asimtomatik & 8 & 19,0 & 22 & 55,0 & \\
\hline Jumlah & 42 & 100 & 40 & 100 & 82 \\
\hline
\end{tabular}

Tabel 3. Dimensi Kesehatan Fisik Klien HIV (+) yang Menggunakan dan Tidak Menggunakan Antiretroviral Therapy

\begin{tabular}{|c|c|c|c|c|c|}
\hline \multirow{2}{*}{ Item Dimensi Kesehatan Fisik } & \multicolumn{2}{|c|}{$\begin{array}{l}\text { Klien HIV (+) yang } \\
\text { Menggunakan ART }\end{array}$} & \multicolumn{2}{|c|}{$\begin{array}{c}\text { Klien HIV (+) yang Tidak } \\
\text { Menggunakan ART }\end{array}$} & \multirow{2}{*}{$\begin{array}{c}\sum \text { Total } \\
\text { Responden }\end{array}$} \\
\hline & $\overline{\bar{X}}$ & SD & $\overline{\bar{X}}$ & SD & \\
\hline 1. Nyeri dan ketidaknyamanan & 3,50 & 0,91 & 3,01 & 0,96 & \\
\hline $\begin{array}{l}\text { 2. Kebutuhan terhadap } \\
\text { pertolongan medis untuk dapat } \\
\text { berfungsi dalam kehidupan } \\
\text { sehari-hari }\end{array}$ & 3,23 & 0,78 & 3,49 & 1,009 & \\
\hline 3. Energi dan kelelahan & 3,47 & 0,73 & 2,95 & 0,69 & \\
\hline 4. Kemampuan bergaul & 4,07 & 0,93 & 3,40 & 0,79 & \\
\hline 5. Istirahat dan tidur & 3,19 & 0,98 & 2,87 & 0,97 & \\
\hline 6. Aktifitas hidup sehari-hari & 3,51 & 0,91 & 3,12 & 0,58 & \\
\hline $\begin{array}{l}\text { 7. Kemampuan } \\
\text { beraktifitas/bekerja }\end{array}$ & 3,37 & 0,97 & 2,84 & 0,69 & \\
\hline$\sum$ Responden & & 42 & & 40 & 82 \\
\hline
\end{tabular}

Tabel 4. Dimensi Psikologis Klien HIV (+) yang Menggunakan dan tidak Menggunakan Antiretroviral Therapy

\begin{tabular}{|c|c|c|c|c|c|}
\hline \multirow[t]{2}{*}{ Item Dimensi Psikologis } & \multicolumn{2}{|c|}{$\begin{array}{l}\text { Klien HIV (+) yang } \\
\text { Menggunakan ART }\end{array}$} & \multicolumn{2}{|c|}{$\begin{array}{c}\text { Klien HIV (+) yang Tidak } \\
\text { Menggunakan ART }\end{array}$} & \multirow{2}{*}{$\underset{\text { Responden }}{\sum \text { Total }}$} \\
\hline & $\overline{\bar{X}}$ & SD & $\bar{X}$ & SD & \\
\hline 1. Perasaan positif & 3,58 & 0,76 & 3,26 & 0,75 & \\
\hline 2. Spiritualitas & 3,30 & 0,87 & 3,45 & 1,04 & \\
\hline $\begin{array}{l}\text { 3. Berpikir, belajar, daya ingat, } \\
\text { dan konsentrasi }\end{array}$ & 3,21 & 0,89 & 3,00 & 0,84 & \\
\hline 4. Gambaran diri/body image & 3,51 & 0,96 & 2,81 & 0,82 & \\
\hline 5. Harga diri & 3,49 & 0,74 & 2,95 & 0,68 & \\
\hline 6. Perasaan negatif & 2,94 & 0,98 & 3,09 & 1,19 & \\
\hline$\sum$ Responden & & 42 & & 40 & 82 \\
\hline
\end{tabular}


Dari tabel 4 diatas dapat diinterpretasikan bahwa pada dimensi psikologis, klien HIV (+) yang menggunakan ART lebih puas akan perasaan positif terhadap hidup/kenikmatan hidup dibandingkan perasaan negatifnya. Sedangkan klien HIV (+) yang tidak menggunakan ART lebih puas terhadap kondisi spiritualitasnya dan kurang puas terhadap gambaran diri/body imagenya.

Dari tabel 5 dapat diinterpretasikan bahwa pada dimensi psikologis, klien HIV (+) yang menggunakan ART lebih puas akan hubungan pribadinya. Sedangkan klien HIV $(+)$ yang tidak menggunakan ART lebih puas terhadap dukungan sosial yang diterimanya. Kedua responden merasa kurang puas terhadap aktifitas seksualnya.

Dari tabel 6 dapat diinterpretasikan bahwa pada dimensi lingkungan, klien HIV (+) yang menggunakan dan tidak menggunakan ART lebih puas terhadap akses dan kesempatan untuk mendapatkan keterampilan dan informasi baru, kemudian mereka juga kurang puas terhadap sumber keuangannya.

Tabel 5. Dimensi Hubungan Sosial Klien HIV (+) yang Menggunakan dan Tidak Menggunakan Antiretroviral Therapy

\begin{tabular}{|c|c|c|c|c|c|}
\hline \multirow{2}{*}{ Item Dimensi Hubungan Sosial } & \multicolumn{2}{|c|}{$\begin{array}{l}\text { Klien HIV (+) yang } \\
\text { Menggunakan ART }\end{array}$} & \multicolumn{2}{|c|}{$\begin{array}{c}\text { Klien HIV (+) yang Tidak } \\
\text { Menggunakan ART }\end{array}$} & \multirow{2}{*}{$\underset{\text { Responden }}{\sum \text { Total }}$} \\
\hline & $\bar{X}$ & SD & $\bar{X}$ & SD & \\
\hline 1. Hubungan pribadi & 3,33 & 0,89 & 2,89 & 0,81 & \\
\hline 2. Aktifitas seksual & 2,81 & 0,82 & 2,65 & 0,92 & \\
\hline 3. Dukungan sosial & 3,29 & 1,03 & 3,24 & 1,04 & \\
\hline$\sum$ Responden & & 42 & & 40 & 82 \\
\hline
\end{tabular}

Tabel 6. Dimensi Lingkungan Klien HIV (+) yang Menggunakan dan tidak Menggunakan Antiretroviral Therapy di Bandung

\begin{tabular}{|c|c|c|c|c|c|}
\hline \multirow[t]{2}{*}{ Item Dimensi Lingkungan } & \multicolumn{2}{|c|}{$\begin{array}{l}\text { Klien HIV (+) yang } \\
\text { Menggunakan ART }\end{array}$} & \multicolumn{2}{|c|}{$\begin{array}{c}\text { Klien HIV (+) yang Tidak } \\
\text { Menggunakan ART }\end{array}$} & \multirow{2}{*}{$\underset{\text { Responden }}{\sum \text { Total }}$} \\
\hline & $\bar{X}$ & SD & $\overline{\bar{X}}$ & SD & \\
\hline $\begin{array}{l}\text { 1. Keselamatan dan keamanan } \\
\text { fisik }\end{array}$ & 3,00 & 0,91 & 2,70 & 0,80 & \\
\hline $\begin{array}{l}\text { 2. Lingkungan fisik (polusi, } \\
\text { keramaian, lalu lintas, cuaca) }\end{array}$ & 3,05 & & 2,88 & 0,73 & \\
\hline 3. Sumber penghasilan & 2,79 & 0,88 & 2,47 & 0,63 & \\
\hline $\begin{array}{l}\text { 4. Kesempatan untuk mendapatkan } \\
\text { keterampilan dan informasi } \\
\text { baru }\end{array}$ & 4,21 & 0,72 & 3,56 & 0,79 & \\
\hline $\begin{array}{l}\text { 5.Berpartisifasi/mempunyai } \\
\text { kesempatan untuk rekresi }\end{array}$ & 3,05 & 0,99 & 2,77 & 0,86 & \\
\hline 6.Lingkungan rumah & 3,26 & 0,45 & 3,12 & 0,75 & \\
\hline $\begin{array}{l}\text { 7.Akses dan kualitas pelayanan } \\
\text { kesehatan }\end{array}$ & 3,93 & 0,48 & 3,47 & 0,73 & \\
\hline 8.Sarana transportasi & 2,84 & 0,7 & 2,86 & 0,60 & \\
\hline$\sum$ Responden & & 42 & & 40 & 82 \\
\hline
\end{tabular}

\section{Perbedaan Kualitas Hidup Klien HIV (+) yang Menggunakan dan tidak Menggunakan Antiretroviral Therapy}

Hasil perhitungan uji $t$ independent sample untuk dimensi kesehatan fisik, diperoleh nilai t hitung $=3,965$, probabilitas 0,000 dengan derajat kebebasan 80 dan tingkat signifikansi $(\alpha) 5 \%$, didapatkan harga $\mathrm{t}$ tabel $=2,000$ yang berarti Ho ditolak. Sehingga terbukti terdapat perbedaan pada dimensi kesehatan fisik klien HIV (+) yang menggunakan dan tidak menggunakan Antiretroiral Therapy. 
Dimensi Psikologis, diperoleh nilai $\mathrm{t}$ hitung $=1,720$, probabilitas 0,089 dengan derajat kebebasan 80 dan tingkat signifikansi (a) $5 \%$, didapatkan harga $t$ tabel $=2,000$ yang berarti Ho diterima. Hal tersebut membuktikan bahwa tidak terdapat perbedaan pada dimensi psikologis klien HIV $(+)$ yang menggunakan dan tidak menggunakan Antiretroiral Therapy.

Dimensi hubungan sosial, diperoleh $\mathrm{t}$ hitung $=2,882$, nilai probabilitasnya 0,005 dengan derajat kebebasan 80 dan tingkat signifikansi $(\alpha) 5 \%$, didapatkan harga t tabel $=2,000$ yang berarti Ho ditolak sehingga terbukti terdapat perbedaan pada dimensi hubungan sosial klien HIV (+) yang menggunakan dan tidak menggunakan Antiretroiral Therapy.

Dimensi lingkungan diperoleh thitung $=2,867$, probabilitasnya 0,005 dengan derajat kebebasan 80 dan tingkat signifikansi ( $\alpha$ ) 5\%, didapatkan harga $t$ tabel $=2,000$ yang berarti Ho ditolak. Sehingga terbukti terdapat perbedaan pada dimensi lingkungan klien HIV (+) yang menggunakan dan tidak menggunakan Antiretroiral

\section{PEMBAHASAN}

Berdasarkan hasil penelitian, menunjukan bahwa terdapat perbedaan yang bermakna pada dimensi kesehatan fisik, yaitu dimensi kesehatan fisik klien HIV (+) yang menggunakan ART lebih baik daripada klien HIV (+) yang tidak menggunakan ART. Penggunaan ART pada klien HIV (+) akan memberikan pengaruh terhadap dimensi kesehatan fisiknya. Obat antiretroviral (ARV) bekerja untuk mengurangi replikasi virus sehingga dapat menghambat perjalanan penyakit HIV. Untuk orang yang belum mempunyai gejala AIDS, ART akan mengurangi kemungkinan menjadi sakit. Selain itu, ART juga bermanfaat dalam meningkatkan dan mempertahankan sel CD4 dalam jumlah yang lebih tinggi serta mengurangi jumlah virus dalam darah sehingga klien bisa menjadi lebih baik dan sehat dari kondisi sebelumnya. Apabila tidak ada ART, perubahan infeksi HIV menjadi AIDS rata-rata 9-10 tahun, dan rata-rata waktu hidup setelah mengalami AIDS hanya sekitar 9,2 bulan. Rata-rata pada tiap orang bervariasi secara luas, dari 2 minggu sampai 20 tahun (Alcorn, 2007).

Pada klien HIV (+) yang tidak menggunakan ART, kebutuhan terhadap pertolongan medis untuk dapat berfungsi optimal dalam kehidupan sehari-hari menempati urutan yang pertama diantara dimensi kesehatan fisik yang lain. Klien puas terhadap kebutuhan pertolongan medis untuk dapat berfungsi optimal dalam melaksanakan kegiatan sehari-hari. Pada klien HIV (+) yang tidak menggunakan ART, klien merasa kurang puas terhadap kemampuanya untuk melaksanakan aktifitas atau bekerja.

Dimensi psikologis klien HIV (+) yang menggunakan ART tidak berbeda dengan dimensi psikologis klien HIV $(+)$ yang tidak menggunakan ART. Pada klien HIV (+) yang menggunakan ART, klien lebih puas terhadap perasaan positif yang dimilikinya dibandingkan aspek lain dalam dimensi psikologisnya. Pada klien HIV (+) yang menggunakan ART aspek dalam dimensi psikologis klien yang menempati urutan paling rendah yaitu perasaan negatifnya. Klien HIV (+) yang tidak menggunakan ART, spiritualitasnya menempati urutan pertama dari aspek-aspek lain dimensi psikologis. Pada klien HIV $(+)$ yang tidak menggunakan ART, gambaran body image nya lebih rendah diantara keseluruhan aspek dimensi psikolgis.

$$
\text { Berdasarkan hasil penelitian, }
$$

menunjukan bahwa terdapat perbedaan dimensi hubungan sosial yang bermakna, yaitu dimensi hubungan sosial klien HIV $(+)$ yang menggunakan ART lebih baik daripada klien HIV $(+)$ yang tidak menggunakan ART. Padilla (1990) mengindikasikan bahwa fungsi peran sosial terdiri dari bagaimana membuat seseorang bahagia (memuaskan orang lain dan membantu orang lain) dan pemenuhan peran sosial seseorang ( menjadi orang tua 
yang baik, anggota komunitas) merupakan pokok dari kebanyakan pasien dalam mempersepsikan kualitas hidupnya dalam waktu yang baik atupun yang buruk.

HIV tidak hanya menjadi masalah biopsikologis, tetapi juga akan berakibat pada kehidupan psikososialnya. Klien HIV (+) yang menggunakan ART merasa lebih puas terhadap hubungan pribadi/sosialnya. Pada klien HIV (+) yang tidak menggunakan ART lebih puas terhadap dukungan sosial yang diperolehnya. Dukungan sosial merupakan suatu bentuk hubungan interpersonal yang dapat melindungi seseorang, karena pada umumnya seseorang yang memiliki sistem pendukung yang kuat akan memiliki kerentanan terhadap penyakit fisik dan mental yang rendah (Kaplan \& Sadock, 2007). Kepuasan terhadap hubungan seksual menempati urutan terkahir pada klien HIV (+)yang menggunakan dan tidakmenggunakan ART. Klien merasa kurang puas terhadap hubungan seksualnya

Berdasarkan hasil penelitian, dimensi lingkungan klien HIV $(+)$ yang menggunakan ART lebih baik daripada klien HIV (+) yang tidak menggunakan ART. Pada dimensi lingkungan, klien HIV (+) yang menggunakan dan tidak menggunakan ART merasa lebih puas terhadap kesempatan untuk mendapatkan keterampilan dan informasi baru. Kepuasan terhadap sumber penghasilan menempati urutan terakhir dari dari keseluruhan aspek dalam dimensi lingkungan baik pada klien HIV $(+)$ yang mengguanakn ART maupun yang tidak menggunakan ART.

Dengan mengetahui perbedaan dimensi kualitas hidup klien HIV (+) yang menggunakan dan tidak mengguanakan ART, perawat yang memberikan pelayanan kesehatan untuk klien HIV $(+)$ dapat memberikan pelayanan berupa tindakan keperawatan yang komprehensif, dan dapat memprioritaskan intervensi keperawatan yang harus diberikan dan sumber-sumber yang dibutuhkan untuk membantu dalam mencapai fungsi yang optimal, serta membantu meningkatkan dan mempertahankan kualitas hidupnya. Untuk mengatasi masalah gangguan istirahat dan tidur perawat dapat menganjurkan klien untuk menjalankan terapi non farmakologis seperti : latihan realaksasi dengan tarik napas dalam atau berendam di air hangat seblum tidur, pengaturan diet dengan misalnya menghindari makanan dengan bumbu menyengat, kafein, alkohol, karbohidrat sederhana (gula\&sirup), makanan berpengawet dan makanan kaleng. Kemudian untuk mengatasi ketidakpuasan terhadap hubungan seksualnya, perawat bisa memberikan saran kepada klien untuk melaksanakan teknik transmutasi seksual atau dengan menyarankan klien menikah dengan HIV (+) juga.

\section{SIMPULAN}

Hasil penelitian dan pengelolaan data mengenai perbandingan kualitas hidup klien HIV (+) yang menggunakan dan tidak menggunkan Antiretroviral Therapy, didapat kesimpulan sebagai berikut: 1) Dimensi kesehatan fisik klien HIV (+) yang menggunakan ART lebih baik dibandingkan klien HIV (+) yang tidak menggunakan ART. Pada klien HIV (+) yang menggunakan ART, aspek pada dimensi kesehatan fisik yang paling tinggi urutan kepuasannya yaitu kemampuan bergaul dan paling rendah kepuasan yaitu istirahat dan tidurnya. 2) Dimensi psikologis klien HIV (+) yang menggunakan ART tidak berbeda dengan klien HIV (+) yang tidak menggunakan ART. Pada klien HIV $(+)$ yang menggunakan ART, aspek pada dimensi psikologis yang paling tinggi urutan kepuasannya yaitu perasaan positif yang dimilikinya dan paling rendah yaitu perasaan negatif. 3). Dimensi hubungan sosial klien HIV $(+)$ yang menggunakan ART lebih baik dibandingkan klien HIV $(+)$ yang tidak menggunakan ART. Pada klien HIV $(+)$ yang menggunakan ART, aspek pada dimensi hubungan sosial yang paling tinggi urutan kepuasannya yaitu hubungan pribadinya sedangkan pada klien HIV $(+)$ yang tidak 
menggunakan ART, aspek pada dimensi kesehatan fisik yang paling tinggi urutan kepuasannya yaitu dukungan social yang diperolehnya. 4). Dimensi lingkungan klien HIV (+) yang menggunakan ART lebih baik dibandingkan klien HIV (+) yang tidak menggunakan ART. Pada klien HIV $(+)$ yang menggunakan dan tidak menggunakan ART, aspek pada dimensi lingkungan yang paling tinggi urutan kepuasannya yaitu kesempatan untuk mendapatkan keterampilan dan informasi baru.

\section{DAFTAR PUSTAKA}

Arikunto, S. 2002. Prosedur Penelitian : Suatu Pendekatan Praktek. Jakarta:Rineka Cipta

Depkes.2014.Pedoman Nasional Terapi Antiretroviral. Available onlinehttp://www. google/depkes/AntiretroviralThepapy.htm.

Depkes. 2015. Farmakologi Obat ARV. Available on line at http://www.google/depkes/ AntiretroviralThepapy.htm.diakses pada 23 Februari 2015.

Dinkes Jawa Barat. 2015. Data Kumulatif HIV/AIDS sampai 31 Desember 2015. Bandung; Dinkes Jabar.

Gunawan, Andi. 2006. Master Asuhan keperawatan KMB untuk ODAH.Available on line at http://www.psikunsri.com/ masterasuhankeperawatankmb.htm.diakses pada 23 Februari 2013.

Ibrahim, K. 2004. Coping and Quality of Life among Patients with Chronic Renal Failure Undergoing Hemodiálisis and Their Spouse. Master Thesis. Prince Songkla University.

King, Cynthia R \& Hinds, Pamela S.1998. Quality of Life : From Nursing and Patient Perspectives. Canada : Jones and Barlett Publisher.

Komisi Penanggulangan HIV/AIDS. 2015. Pengertian, Penularan, Pencegahan HIV/AIDS. Available online at http://www. google.com/KPA/definision,tansmision,prev ention,HIV/AIDS.htm.Diakses tanggal 30 November 2015

Keliat, Budi Anna dkk.2006.Proses Keperawatan Kesehatan Jiwa Edisi 2.Jakarta:EGC

Louwagie, Goedele. dkk. 2007. Highly active antiretroviral treatment and health related quality of life in South African adults with human immunodeficiency virus infection: $A$ cross-sectional analytical study. Available on line http://www.bmcpublichealth.com diakses pada 23 Februari 2014.

Mills, R. (1996). The Pleasure of Health, the Joys of Illness, and the delight of longing to meet my Maker-The Islamic Perspective on Life and Death. Diakses pada 28 Maret 2013.

Muna, RD.1997. AIDS di Indonesia : Masalah dan Kebijakan Penanngulangannya.Jakarta : EGC Wicaksono.Rudy.2004.KonsepDasar HIV/AIDS.Bandung: FK Unpad.

WHO.2004.WHO Quality of Life-Bref (WHO QolHIVBref).Availableonlinehttp://www.who.int /sustanceabuse/researc'tools/whoqolbref/en/i ndex.hhtml. Diakses pada 30 November 2007.

Zhan MS, Lin. 1992. Quality of life: conceptual and measurement issues. Journal of Advance Nursing, 17, 795-800.

Naveet,Wig.dkk. 2008. The impact of HIV/AIDS on the quality of life: A cross sectional study in north India. Available online http://indianjournalofmedicalsciens.com.diak ses pada tanggal 23 Februari 2014.

Nursalam, Ninuk Dian Kurniawati.2007. Asuhan Keperawatan Pada Pasien Terinfeksi. Jakarta: Salemba Medika.

Programme on mental health World Health Organization Geneva. whoqol-bref introducion, scoring and generic version of the assessment. Available online at http: //www.popcouncil.org/horizons/AIDSquest/i nstrument/whoqolbref.pdf. diakses pada 11 Mei 2013.

Polit,Denise F\&Chery tatato Beck.2010. Nursing Reaserch: Philadelphia. Lippincott Williams \& Wilkins.

Saxena,Shekhar.2002.Cross-Cultural Quality-ofLife Assessment at the End of Life. Available online http://www.google/agework.com/ WHOQOL MODUL.htm. Diakses pada 30 November 2013.

Sugiyono.2006. Metode penelitian Administrasi. ALFABET: Bandung.

Suryadi, Andi.2007. Diskriminasi pada ODHA. Available on line at http://www.google.com. Diakses pada tangggal 24 Juni 2010. 